\title{
Models of Short Bowel Syndrome in Pigs: A Technical Review
}

\author{
S. Weih ${ }^{a} \quad$ A. Nickkholgh ${ }^{b} \quad$ M. Kessler ${ }^{a} \quad$ G. Frongia $^{a} \quad$ M. Hafezi ${ }^{b}$ \\ M. Golriz ${ }^{b} \quad$ N. Fard ${ }^{b} \quad$ S. Holland-Cunz ${ }^{a} \quad$ A. Mehrabi ${ }^{b}$ \\ Departments of a Pediatric Surgery and ${ }^{b}$ General, Visceral and Transplant Surgery, \\ University of Heidelberg, Heidelberg, Germany
}

\section{Key Words}

Intestine $\cdot$ Porcine model $\cdot$ Small bowel $\cdot$ Small bowel transplantation $\cdot$ Short bowel syndrome $\cdot$ Surgical interventions

\begin{abstract}
Background: Short bowel syndrome (SBS) is still a life-threatening disease in both children and adults. Although the therapeutic options are improving, challenges still remain, and to overcome these challenges is a major focus of SBS research today. In order to simulate anatomical and physiological conditions similar to those in humans for research, porcine models of SBS are often used. Various approaches for generating SBS models have been described in the literature. Methods/Results: In this work, we present a review of different types of porcine models of SBS and outline the differences between those models regarding types of animals, surgical procedures, monitoring, and methods of assessment. Conclusion: The aim of this study was to select the most suitable SBS model regarding the purpose of the research.
\end{abstract}

\section{Introduction}

Short bowel syndrome (SBS) is generally defined as a disorder in which the resorptive capacity of the intestine is not sufficient to provide an adequate alimentary supply due to anatomical or functional reasons [1, 2]. The incidence of SBS is increasing [3] and varies between 2 and 5 patients per million $[1,2,4]$. As total enteral alimentation is not possible in SBS patients, nutrition must be provided parenterally at least partially $[1,5]$. The 5-year

S. Holland-Cunz and A. Mehrabi contributed equally to this work. 
survival rate for patients receiving parental nutrition (PN) is 63\% [6]. To optimize the patients' survival and quality of life, bowel-lengthening procedures, such as the Bianchi or serial transverse enteroplasty (STEP) technique [7,8], or small bowel transplantation (SBTx) has been adopted. In the last decade, modern therapeutic options such as tissue engineering [9] have been among the topics of interest. Due to the anatomical and physiological similarities to humans, porcine models are useful for optimizing different therapeutic approaches [10-14]. There are various and sometimes not exact definitions of SBS in the literature. Moreover, different researchers have used different methods to assess their results. Therefore, an SBS researcher may find it difficult to find a standardized SBS model as well as assessment methods. The aim of this work was to present an overview of these different models regarding the techniques used to induce an SBS model and the variety of assessment methods employed, and to evaluate the advantages and disadvantages of each model in order to help the SBS researcher select the best suitable model according to the aim of their research.

\section{Materials and Methods}

An analysis of all MEDLINE-published porcine models of SBS up to December 2011 was performed. Search items included 'short bowel syndrome', 'model', 'intestinal failure', 'pig', 'swine', 'porcine', 'parenteral nutrition', 'small bowel transplantation', 'lengthening procedures', 'surgical options' ‘stimulants', and 'intestinal transit'. We evaluated publications in English, German, Spanish, and French; articles published in other languages and those presenting insufficient data were excluded from the literature review. Particular attention was paid to the definition, surgical aspects and monitoring or assessment methods in the conducted SBS models. To avoid reviewing repetitive cases, review articles or double publications were omitted; however, the reference lists were cross-checked for additional useful articles. To optimize our search and the quality of analysis, the instructions of the Quality of Reports of Meta-analyses (QUOROM) [15] were followed. The MEDLINE analysis revealed 814 publications. Inclusion criteria were the use of a porcine SBS model and a description of how much bowel was resected. The application of these criteria resulted in 27 publications which were included in the final analysis (fig. 1).

Biometrical data, operative data (including different methods, the percentage and the anatomical location of resection), length of observation, as well as methods of monitoring the animals including nutritional assessment, weight changes, food intake, clinical status and lab data were evaluated. Functional, morphological, and molecular assessments were also evaluated, and the mortalities of the SBS models were outlined.

\section{Results}

\section{Animals}

The majority of studies used domestic pigs or piglets [5, 13, 16-19] mainly of female gender $[10,13,16,18,20-29]$. Regarding the exact breed, mostly landrace $[10,21,22,30,31]$ or landrace $\times$ large white $[5,13,16,20,24,26,32-34]$ animals were used. SBS models were seldom described in other types of pig [7, 23]. Male animals were used rarely [31, 34, 35].

The age as well as the weight $[7,10,18,25,27,28,30,31,36]$ of the pigs at the time of surgery varied widely. In some cases, the pigs were younger than 7 days $[21,29,34,37]$, but in most cases they were between 3 and 8 weeks [13, 16, 18, 20, 24, 26-28, 32, 33]. In rare cases, older pigs (3-7 months) were chosen [5, 7]. Few authors used animals with less than $10 \mathrm{~kg}$ body weight $[29,34,35]$, with the majority of animal models weighing $10-30 \mathrm{~kg}$.

\section{Anesthesia}

As anesthesia was not the focus of the analyzed models, it was often not described extensively and many authors did not explain how they performed anesthesia at all $[20,23,26,32$, 
Fig. 1. Screening design together with the summarized number of screened abstracts and the relevant and suitable articles identified during the review process, using the modified flow chart according to the QUOROM statement [15].

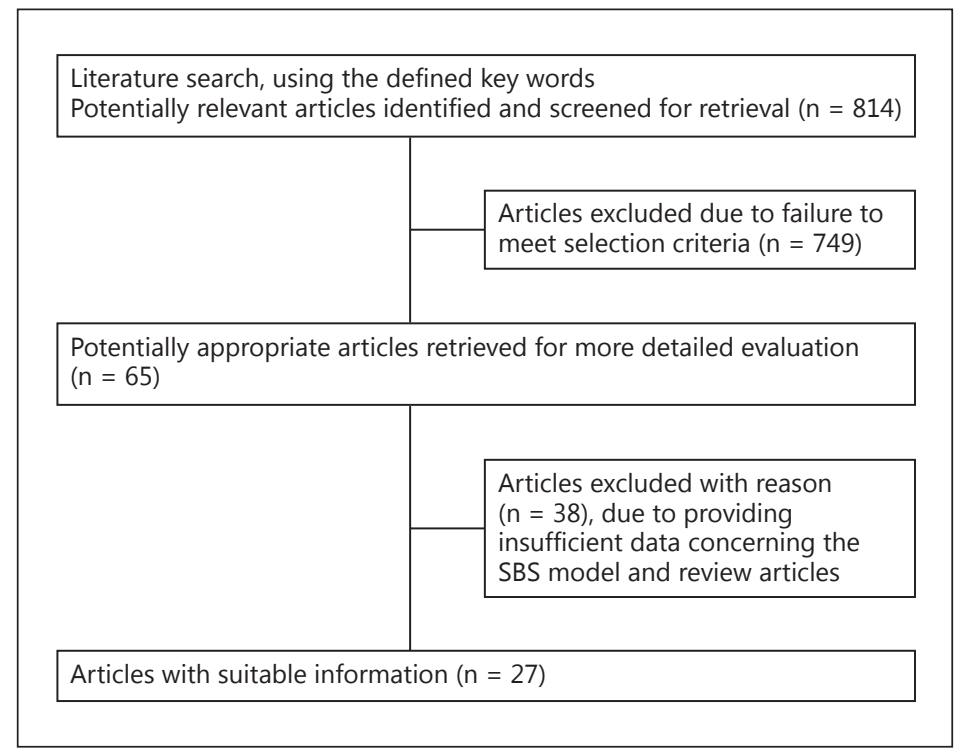

$33,36,38-40]$. If mentioned, most often anesthesia with halothane and oxygen $[17,18,21$, $24,27]$ or isoflurane $[19,37]$ was performed, sometimes in combination with ketamine and azaperone [7]. In rare occasions, other strategies such as anesthesia with propofol, fentanyl and pancuronium [5], thiopental sodium and ketamine [7], or a combination of the mentioned drugs $[29,41]$ were chosen. Specific anesthesiologic problems concerning SBS have not been mentioned.

\section{Surgical Procedures for Inducing SBS}

Data concerning the extension and location of resection, associated interventions and period of observation are summarized in table 1.

The percentage of the resected small bowel ranged from 75 to $100 \%$. Seventy-three percent of the authors performed a resection of $75 \%[10,13,16,18,21,22,24,26-28,32-34]$ or $80 \%$ of the small bowel $[5,29,30,35,37]$, and in 8 and $19 \%$ of the articles, $90 \%[19,23]$ and $95-100 \%[7,25,30,31,36]$ of the small bowel was resected, respectively. The bowel was resected in two main areas: most of the authors described a mid-intestinal resection in which the remaining small bowel consists of equal parts of the jejunum and ileum $[5,10,18,21,22$, $27-31,34,35]$; other authors used a $75 \%$ resection model in which the jejunum was resected $0.5[24,26,32]$ to $1 \mathrm{~m}[20,33]$ distal of the ligament of Treitz proximally and the ileum up to $2.5 \mathrm{~m}$ proximal to the ileocecal valve distally $[13,16,20,24,26,32,33]$. No author described a resection of the ileocecal valve. In those publications that described the surgical technique in detail, only end-to-end anastomoses were reported [5, 21, 22, 24, 26, 29, 32, 34, 35, 37]; the anastomoses were mainly performed in a single-layer technique $[5,10,19,25-28,32]$ with interrupted sutures $[21,22,24,26-28,32,34,35,37]$. Running sutures were rarely observed $[10,18,25]$. While the use of 4-0, 5-0 and 8-0 silk sutures was reported, other nonabsorbable sutures such as 4-0 polypropylene were also described [19, 27, 28, 35, 37]. However, the material was predominantly nonmonofilament absorbable sutures such as 5-0 Dexon [24, 26, 32] or 4-0 Polysorb [21, 22]. Anastomoses with monofilament absorbable sutures such as 5-0 polyglyconate [25] or 3-0 polydioxanone [10] were also performed.

Surgical or nonsurgical interventions besides extended bowel resection included SBTx $[25,31,36]$, bowel-lengthening procedures $[18,19,23,28]$, bowel dilatation $[7,28]$ or phar- 
Table 1. Percentage and location of resection, interventions performed and time period of observation

\begin{tabular}{|c|c|c|c|c|c|c|}
\hline \multirow[t]{2}{*}{ First author } & \multicolumn{2}{|l|}{ Resection } & \multicolumn{3}{|c|}{ Additional intervention } & \multirow{2}{*}{$\begin{array}{l}\text { Period of } \\
\text { observation }\end{array}$} \\
\hline & $\begin{array}{l}\text { percent- } \\
\text { age }\end{array}$ & location & $\begin{array}{l}\text { further } \\
\text { operation }\end{array}$ & type & sequence & \\
\hline Llanos [36], 2006 & 100 & jejunum and ileum & yes & SBTx & simultaneously & 19 weeks \\
\hline Sano [31], 2001 & 100 & jejunum and ileum & yes & SBTx & simultaneously & 14 days \\
\hline Sano [30], 2002 & 100 & not mentioned & no & no & - & 19 weeks \\
\hline Kimura [47], 1990 & 100 & jejunum and ileum & no & no & - & $>180$ days \\
\hline Pakarinen [25], 1996 & $>95$ & jejunum and ileum & yes & SBTx & simultaneously & 12 weeks \\
\hline Sacher [7], 1997 & $\begin{array}{l}95 \\
95 \\
95\end{array}$ & $\begin{array}{l}\text { jejunum and ileum } \\
\text { to } 15 \mathrm{~cm} \text { prox. to ileocecal valve } \\
\text { jejunum and ileum } \\
\text { to } 5 \mathrm{~cm} \text { prox. to ileocecal valve } \\
\text { jejunum and ileum } \\
\text { to } 5 \mathrm{~cm} \text { prox. to ileocecal valve }\end{array}$ & yes & intestinal banding & simultaneously & 10 weeks \\
\hline Chang [19], 2006 & 90 & not mentioned & yes & STEP procedure & simultaneously & 6 weeks \\
\hline Modi [23], 2009 & 90 & not mentioned & yes & STEP procedure & sequentially & 18 weeks \\
\hline Taguchi [29], 2005 & 80 & same length of jejunum and ileum & yes & bypass operation & simultaneously & 2 weeks \\
\hline Digalakis [5], 2011 & 80 & same length of jejunum and ileum & yes & reverse bowel segment & simultaneously & 8 weeks \\
\hline Bartholome [37], 2004 & 80 & $\begin{array}{l}15 \mathrm{~cm} \text { distal to ligament of Treitz } \\
\text { to } 75 \mathrm{~cm} \text { prox. to ileocecal valve }\end{array}$ & no & no & - & 7 days \\
\hline Benhamou [35], 1997 & 80 & same length of jejunum and ileum & no & no & - & 4 weeks \\
\hline Buie [18], 1993 & 75 & same length of jejunum and ileum & yes & Bianchi procedure & sequentially & 18 weeks \\
\hline Sigalet [28], 2001 & 75 & same length of jejunum and ileum & yes & $\begin{array}{l}\text { bowel lengthening } \\
\text { colon interposition } \\
\text { cimetidine and codeine }\end{array}$ & $\begin{array}{l}\text { sequentially } \\
\text { sequentially }\end{array}$ & 16 weeks \\
\hline $\begin{array}{l}\text { Pereira-Fantini [32], } \\
2008\end{array}$ & 75 & $\begin{array}{l}0.5 \mathrm{~m} \text { distal to ligament of Treitz } \\
\text { to } 2.5 \mathrm{~m} \text { prox. to ileocecal valve }\end{array}$ & no & GLP-2 application & - & $6-8$ weeks \\
\hline $\begin{array}{l}\text { Pereira-Fantini [16], } \\
2008\end{array}$ & 75 & $1 \mathrm{~m}$ distal to ligament of Treitz to $2.5 \mathrm{~m}$ & no & no & - & 8 weeks \\
\hline $\begin{array}{l}\text { Pereira-Fantini [13], } \\
2011\end{array}$ & 75 & prox. to ileocecal valve & no & no & - & 6 weeks \\
\hline Welters [10], 1996 & 75 & same length of jejunum and ileum & no & butyrate application & - & 3 weeks \\
\hline Healey [20], 2010 & 75 & $\begin{array}{l}1 \mathrm{~m} \text { distal to ligament of Treitz } \\
\text { to } 2.5 \mathrm{~m} \text { prox. to ileocecal valve }\end{array}$ & no & no & - & 6 weeks \\
\hline Heemskerk [21], 1999 & 75 & same length of jejunum and ileum & no & no & - & 4 weeks \\
\hline Heemskerk [22], 2002 & 75 & same length of jejunum and ileum & no & no & - & 4 weeks \\
\hline Nagy [24], 2004 & 75 & $\begin{array}{l}0.5 \mathrm{~m} \text { distal to ligament of Treitz } \\
\text { to } 2.5 \mathrm{~m} \text { prox. to ileocecal valve }\end{array}$ & no & no & - & 8 weeks \\
\hline Paris [26], 2004 & 75 & $\begin{array}{l}0.5 \mathrm{~m} \text { distal to ligament of Treitz } \\
\text { to } 2.5 \mathrm{~m} \text { prox. to ileocecal valve }\end{array}$ & no & no & - & 8 weeks \\
\hline Del Olmo [40], 1998 & 75 & not mentioned & no & no & - & 24 weeks \\
\hline Sigalet [27], 1990 & 75 & same length of jejunum and ileum & no & no & - & 16 weeks \\
\hline Stephens [33], 2010 & 75 & $\begin{array}{l}1 \mathrm{~m} \text { distal to ligament of Treitz } \\
\text { to } 2.5 \mathrm{~m} \text { prox. to the ileocecal valve }\end{array}$ & no & no & - & 6 weeks \\
\hline Turner [34], 2011 & 75 & same length of jejunum and ileum & no & no & - & $17-21$ days \\
\hline
\end{tabular}

maceutical treatments for SBS [10, 32], often in the course of weeks after the extended bowel resection.

The period of observation varied widely from 7 days [37] up to 19 weeks [30]. Many research groups chose a short-time model up to 4 weeks [10, 21, 22, 31, 34, 35, 37]. Few models selected a follow-up period of 2-3 months [5, 7, 16, 19, 24-26, 32, 33] or even longer (up to $4-5$ months) $[18,23,27,28,30]$.

\section{Objectives of the Different Studies}

The aim of the studies can be divided into the following categories:

- $\quad$ intestinal adaptation to SBS [10, 13, 26, 27, 33, 34]; 
- effects of nutritional [16, 17, 22, 24, 28, 37], hormonal [32, 35] or surgical [5, 36] treatment on intestinal adaption;

- $\quad$ intestinal functions in pigs with SBS [7, 18, 19, 23, 25];

- other objectives such as influences of SBS on liver function or the level of immunosuppressive medication [29-31].

According to the above-mentioned categories, different aspects were important in generating the models. The main differences were regarding nutrition of the animals, the use of histological and special analyses as well as different methods of animal monitoring after the induction of SBS (see below).

\section{Care and Monitoring of the Animals}

Nutrition

Nutrition was provided to the animals in different ways. PN was used in some [29, 34, 37] but not all studies. How and in which vein intravenous lines were placed was frequently not described. Taguchi et al. [29] utilized PN consisting of $64 \mathrm{kcal} / \mathrm{kg} /$ day $(15 \mathrm{~g} / \mathrm{kg} / \mathrm{day}$ glucose, $1.0 \mathrm{~g} / \mathrm{kg} /$ day amino acid) in addition to enteral alimentation. Turner et al. [34] fed their piglets only by PN with target nutrient intakes of $16 \mathrm{~g} / \mathrm{kg} /$ day amino acids, $1.1 \mathrm{MJ} / \mathrm{kg} /$ day energy, $10 \mathrm{~g} / \mathrm{kg} /$ day lipid, and $324 \mathrm{ml} / \mathrm{kg} /$ day fluid. Bartholome et al. [37] used dextrose (50\% glucose monohydrate; Baxter Healthcare Corporation, Deerfield, Ill., USA), amino acids (8.5\% Travasol with electrolytes; Baxter Healthcare Corporation) and lipids (30\% Intralipid; Baxter Healthcare Corporation) equaling $307 \mathrm{kcal} / \mathrm{kg} /$ day and $15.5 \mathrm{~g} / \mathrm{kg} /$ day amino acids for postoperative days $0-3$ and $253 \mathrm{kcal} / \mathrm{kg} /$ day and $12.8 \mathrm{~g} / \mathrm{kg} /$ day for postoperative days 4-7. In models analyzing the influence of enteral nutrition, different diets such as elemental/polymeric formula or chow were provided $[13,16,17,20]$, often supplemented with colostrum [16, 22, 24]. Rarely, other forms of alimentation such as Pezzullo dough pellets (Sun Company, Milan, Italy) [5], Nutrison Steriflo HP (Nutricia, Zoetermeer, The Netherlands) [10], modified infant formula (Nutrilon Premium; Nutricia) or further types were mentioned [5, 10, 21, 32]. Enteral alimentation was sometimes only described unspecifically as a 'standard grower diet' $[27,28,35]$ or 'free access to food' $[7,18,19,31]$ without any detailed dietary information.

Monitoring

Body weight, food intake, stool output, the general condition of the animal and blood tests were used as monitoring criteria. Nearly all of the research groups used body weight to monitor the effect of SBS. In addition to body weight, food intake was also frequently recorded. It was usually measured once a day [17, 24, 26, 34, 35] or once a week [18, 25, 27]. One group also described measuring the food intake once in a fortnight [28]. The evaluation of stool output once a day $[17,24]$ or once a week [25] and obtaining stool samples for microscopic analyses $[20,32]$ (every fortnight) or nutritional studies $[18,34]$ (days to weeks after the first operation) were also often conducted. The general well-being of the animals was only described by a limited number of research groups [17, 24-26, 36, 37]. Where it was analyzed, it was most often recorded once a day [17, 24, 26, 37]. Blood samples were analyzed very irregularly $[7,17-20,25,28,32-34,36]$. The majority of samples were analyzed on the day of the first surgical procedure $[5,7,16,18,19,25,28,29,33,36]$ but postoperative analysis of blood samples varied widely from some days [20, 29, 32, 34] to 18 weeks after the first surgical procedure $[5,18]$. Also, the values measured were very inhomogeneous.

Functional, Morphological, and Molecular Assessment

Measurements of the disaccharidase activity (maltase, sucrase, lactase) [17, 24, 26, 32] in the intestinal tissue as a marker of intestinal function [26], plasma glucagon-like peptide- 2 
Table 2. Laboratory assessment

\begin{tabular}{|c|c|}
\hline First author & Blood samples \\
\hline Kimura [47], 1990 & 'routine laboratory chemistry': not mentioned how often \\
\hline Buie [18], 1993 & at 0,6 , and 18 weeks: $\mathrm{Hb}, \mathrm{Hct}, \mathrm{WBC}$, albumin, protein, $\mathrm{Ca}, \mathrm{P}$ \\
\hline Pakarinen [25], 1996 & $\begin{array}{l}\text { Hb } 1 \times / \text { week } \\
1 \times \text { weeks } 1-4,1 \times \text { weeks } 5-12 \text { : cholesterol, triglyceride, protein, ALP, ALAT, } \\
\text { ASAT, creatinine, sodium, potassium, Cl }\end{array}$ \\
\hline Sacher [7], 1997 & weeks 0 and 10: Hct, protein, sodium, potassium, $\mathrm{Cl}$, iron \\
\hline Sigalet [28], 2001 & $\begin{array}{l}\text { weeks 6-10: blood count, total protein, albumin, glucose, alkaline, } \\
\text { phosphatase, creatinine, LDH, ASAT }\end{array}$ \\
\hline Bines [17], 2002 & $\begin{array}{l}\text { 'frequently': albumin, protein, glucose, calcium, cholesterol, urea, electrolyte, } \\
\text { iron, ASAT, ALAT, GGT }\end{array}$ \\
\hline Taguchi [29], 2005 & days 7 and 14: bilirubin, ASAT, ALAT, bile acid \\
\hline Chang [19], 2006 & $\begin{array}{l}\text { weeks } 6 \text { and 12: 'baseline hematologic parameters', albumin, vitamin D, } \\
\text { triglycerides }\end{array}$ \\
\hline Llanos [36], 2006 & $\begin{array}{l}\text { day of surgery, last measure: total protein, albumin, triglycerides, cholesterol, } \\
\text { glycemia, urea, creatinine }\end{array}$ \\
\hline Pereira-Fantini [32], 2008 & $2 \times /$ month: albumin \\
\hline Digalakis [5], 2011 & 4-8 weeks preop.: albumin \\
\hline Healey [20], 2010 & $2 \times /$ month: $\mathrm{Ca}$, total protein, $\mathrm{Hb}$ \\
\hline Stephens [33], 2010 & weeks 2, 4, and 6: bile acid, cholesterol, triglycerides \\
\hline Turner [34], 2011 & days $0-17 / 21$ : bilirubin, ALAT, ALP, GGT \\
\hline
\end{tabular}

(GLP-2) concentrations [32, 37], and rarely additional measurements of nutrient uptake [18, $27,28]$, D-xylose absorption test [19], motility test [23] or other methods [10, 17, 29] have been described. Concerning the measurement of vitamins, only in one publication [19] was the measurement of vitamin $D$ recorded. The measurement of other vitamins or folic acid was not described. Concerning selenium, zinc or iron measurements, only iron was analyzed in two of the publications evaluated $[7,17]$.

For the purpose of morphological assessment, $72 \%$ of the studies performed histological examinations. The samples were mainly referred to as 'small bowel' without any further specifications [22] or a declaration of the exact location of resection [19, 21, 27, 35, 37]. Specific location descriptions included mainly the duodenum, jejunum and ileum $[5,13,17,24,28,32$, 34]. Colonic samples were rarely used for histological assessment [20]. For the histological assessment, 56\% (9/16) of the research groups analyzed villus height and crypt depth [17, $21,22,24,26,28,32,34,35,37]$. Additionally, in 18\% (3/16) of the studies, measurements of the thickness of the intestinal muscle layer were also performed [17, 32, 35]. Furthermore, $18 \%$ of the groups recorded villus and crypt cell proliferation as well as apoptosis $[13,20$, $32]$. Midvillus width, villus surface area [13,37], villus diameter [35] and total number of villi $[13,28]$ were also analyzed by about $12 \%$ of the research groups. In very rare cases, other analyses such as the evaluation of the total number of cells within the colon crypts, enterocyte cell levels [20,36] or liver biopsies were performed additionally [29, 34].

Molecular assessment was performed in approximately $37 \%(6 / 22)$ of the reviewed articles. In 50\%, DNA or RNA concentrations and ratios were measured in mucosal scrapings taken from different locations of the intestine $[21,22,37]$ to analyze changes on the molecular or the protein level. In addition to these assessments, special genetic analyses such as proglucagone gene expression [17] and different protein analyses were performed. The sampling location for these studies varied widely [20-22, 33, 37]. Measurement of the total protein content in the entire intestinal tissue [37] or mucosa alone [21, 22], or analysis of special 
Table 3. Functional assessment

\begin{tabular}{ll}
\hline First author & Functional assessment \\
\hline Sigalet [27], 1990 & in vitro glucose/lipid uptake of the tissue \\
\hline Buie [18], 1993 & $\begin{array}{l}\text { in vitro glucose uptake and transmural } \\
\text { electrical studies } \\
\text { digestibility coefficients }\end{array}$ \\
\hline Welters [10], 1996 & portal efflux (glucose, amino acids) \\
\hline Sigalet [28], 2001 & in vivo protein, carbohydrate, fat \\
\hline Bines [17], 2002 & $\begin{array}{l}\text { disaccharidase in tissue } \\
\text { transepithelial conductance } \\
\text { Cr-EDTA flux }\end{array}$ \\
\hline Bartholome [37], 2004 & plasma GLP-2 concentrations \\
\hline Nagy [24], 2004 & disaccharidase activity \\
\hline Taguchi [29], 2005 & hepatic circulation/tissue sample \\
\hline Chang [19], 2006 & D-xylose test, fat absorptive capacity (vitamin D, triglyceride levels) \\
\hline Pereira-Fantini [32], 2008 & $\begin{array}{l}\text { GLP-2 plasma levels } \\
\text { disaccharidase activity }\end{array}$ \\
\hline Modi [23], 2009 & motility testing \\
\hline Digalakis [5], 2011 & transit time \\
\hline Turner [34], 2011 & $\begin{array}{l}\text { fecal fat collections } \\
\text { liver biopsy }\end{array}$ \\
\hline
\end{tabular}

Table 4. Molecular assessment

\begin{tabular}{ll}
\hline First author & Molecular assessment \\
\hline Del Olmo [40], 1998 & plasma levels of vasoactive intestinal peptide \\
\hline Heemskerk [21], 1999 & $\begin{array}{l}\text { protein concentration of mucosa } \\
\text { DNA and RNA concentrations and ratios in mucosa scrapings }\end{array}$ \\
\hline Bines [17], 2002 & proglucagon gene expression (intestinal tissue) \\
\hline Heemskerk [22], 2002 & $\begin{array}{l}\text { protein concentration of mucosa } \\
\text { DNA and RNA concentrations and ratios in mucosa scrapings }\end{array}$ \\
\hline Bartholome [37], 2004 & $\begin{array}{l}\text { DNA, RNA, protein content (intestinal tissue) } \\
\text { protein analysis (apoptotic protein and proliferating cell nuclear antigen } \\
\text { protein abundance in intestinal tissue) }\end{array}$ \\
\hline Pereira-Fantini [16], 2008 & $\begin{array}{l}\text { concentration of growth hormone/IGF-1(serum) } \\
\text { RNA content of ileal tissue }\end{array}$ \\
\hline Healey [20], 2010 & analysis of colon mucosa proteins \\
\hline Stephens [33], 2010 & $\begin{array}{l}\text { protein analysis (difference gel electrophoresis, immunoblotting, } \\
\text { immunohistological analysis) of ileal tissue }\end{array}$ \\
\hline
\end{tabular}

proteins $[33,37]$ including the use of difference gel electrophoresis, immunoblotting and immunohistological methods [33] was also performed.

Tables 2-5 give an overview of the functional, morphological and molecular assessments conducted in the different published models.

\section{Discussion}

For the purpose of animal research, pig models are the experimental method of choice because of the substantial anatomical and physiological similarities to humans $[14,17,20,26$, $42,43]$. Moreover, pigs can reliably tolerate extended pathophysiological stress like the 
Table 5. Morphological assessment

\begin{tabular}{ll}
\hline First author & Morphological assessment \\
\hline Heemskerk [21], 1999 & villus height, crypt depth \\
\hline Nagy [24], 2004 & villus height, crypt depth \\
\hline Paris [16], 2004 & villus height, crypt depth \\
\hline Pereira-Fantini [32], 2008 & villus height, crypt depth \\
\hline Turner [34], 2011 & villus height, crypt depth \\
\hline Bines [17], 2002 & villus height, crypt depth + mucosal and muscle layer thickness \\
\hline Bartholome [37], 2004 & villus height, crypt depth + villus width and surface \\
\hline Digalakis [5], 2011 & $\begin{array}{l}\text { villus height, crypt depth + muscular layer thickness, crypt cell proliferation, } \\
\text { apoptosis rate }\end{array}$ \\
\hline Benhamou [38], 1997 & $\begin{array}{l}\text { villus height, crypt depth + crypt to villus ratio, number of mitosis per field, } \\
\text { intestinal muscular layer and wall thickness }\end{array}$ \\
\hline Healey [20], 2010 & $\begin{array}{l}\text { increase of number of crypt colon cells and of apoptotic colon cells, } \\
\text { enterocytes within colonic crypts, enteroendocrine cells and goblet cells in } \\
\text { colon }\end{array}$ \\
\hline Pereira [13], 2011 & $\begin{array}{l}\text { bowel length and width, increase in crypt and villus surface, number of crypt } \\
\text { and villus cells }\end{array}$ \\
\hline Sigalet [28], 2001 & number of villi \\
\hline Heemskerk [22], 2002 & mitotic index \\
\hline Kimura [47], 1990 & mucosal integrity, significant lymphocyte infiltration \\
\hline Chang [19], 2006 & 'structural differences between groups' \\
\hline Llanos [39], 2006 & histologic grading rejection (Murase) \\
\hline Pereira-Fantini [16], 2008 & bowel length, increase in circular muscle area \\
\hline & \\
\hline
\end{tabular}

resection of the small bowel for the purpose of SBS research [27]. Through the analysis of the different porcine models currently in use, we have found that a unanimous definition of SBS, as a disorder, in which an adequate alimentary supply cannot be provided enterally $[1,2]$, still does not exist in the field of surgical research. Therefore, an overview of the various porcine models used seems to be important.

\section{Biometrical Data of the Used Pigs}

Concerning the type and gender of the animals, mainly female landrace pigs were used. This could be due to practical reasons such as easier laparotomy and less risk of urethral injury in female pigs, whereas the urethra in male pigs runs along the laparotomy line. However, this fact has not been mentioned clearly in the literature. In the different experimental models, the following three age groups of animals became evident.

(1) Neonatal pigs up to 7 days of age: neonatal pigs show a similar anatomy, physiology, and metabolism to human neonates [34]. In the neonatal state, nutrient demand is much higher than in older animals [21]. Using 7-day-old piglets, the full clinical spectrum of intestinal failure, as with human neonatal SBS, can be simulated [34]. The size of neonatal piglets permits surgical interventions as well as further treatments and invasive monitoring. Furthermore, these pigs tolerate major surgery and anesthesia easily [21]. Although some groups argue that piglets younger than 7 days may have theoretical advantages for studies analyzing intestinal adaption [34], others advocate the use of 7-day-old piglets in intervention studies due to the high mortality (50\% within $48 \mathrm{~h}$ after surgery) in the group of younger piglets [21].

(2) Pigs between 3 and 8 weeks of age: at the age of 3 weeks, piglets can be weaned from suckling [44]. At 4 weeks of age, those confounding factors which occur at the time of weaning might be avoided [17] and the juvenile pig has anatomical, physiological and biochemical 
similarities to humans and reflects the condition of SBS in infants and children $[13,17,24$, $26]$. The growing pig gains weight rapidly and therefore alterations in weight gain can demonstrate the effects of surgical interventions as an objective parameter following the efficacy of adaptation of nutrient absorption [28]. Additionally, pigs up to $20 \mathrm{~kg}$ can be quickly restrained manually $[45,46]$.

(3) Pigs older than 8 weeks: the rationale for using these pigs is that body weight encompasses the effects of surgery and growth development in this age group [5].

\section{Surgical Procedure}

The mode of surgical intervention ranges widely concerning the percentage and the location of the resected bowel as well as associated procedures in addition to massive bowel resection. Most frequently, a midintestinal resection of $75 \%$ of the bowel was performed. Resections up to $100 \%$ and resections of parts other than the midintestinal part were also described. Selecting the mode of resection depended highly on the authors' definition of SBS, the study aims and the planned period of observation. Sacher and Stauffer [7] defined SBS by weight loss, which was achieved by a $95 \%$ distal intestinal resection preserving the ileocecal valve including a jejunoileal anastomosis. Turner et al. [34] performed different types of resection and presented an SBS model of 75\% distal intestinal resection followed by significantly less weight gain, greater malabsorption and more cholestatic liver disease compared to a midintestinal $75 \%$ resection. Furthermore, Turner et al. [34] selected the distal intestinal resection because this is a common type of resection performed in human neonates. However, Bines et al. [17] justified performing a proximal 75\% intestinal resection for the same reason.

Nonetheless, it was usually not explained why the authors selected a specific type of resection. The duration of the observation period also varied greatly. To evaluate levels of an immunosuppressive drug (FK 506) in SBS after oral application, 7 days of observation seemed adequate [30]. Healey et al. [20] and Pereira-Fantini et al. [13] examined the animals 2, 4 and 6 weeks postoperatively to analyze early and late adaptational responses. In a separate study, Pereira-Fantini et al. [32] chose a period of 6-8 weeks to analyze the influences of GLP-2 treatment on SBS. In contrast to that, Pakarinen et al. [25] declared a period of 5-12 weeks to be necessary for the evaluation of 'long-term effects' after inducing SBS. Kimura et al. [47] defined 'long-term survival' as a period of 180 days. Sigalet et al. [28] observed their pigs for 10 weeks to analyze nutritional effects on SBS, but 16 weeks to monitor the physiology of adaptational processes [27]. This agrees with the findings of Bartholome et al. [37] that functional adaptation takes place during the first months after resection and reaches a plateau after 1-2 years [37]. None of the publications mentioned why a special method of anastomosis was chosen. To improve interventions treating SBS, associated surgical procedures were often performed and SBS itself was not analyzed. This has to be taken into account, especially when complication rates (see above) or different types of monitoring animals are discussed.

\section{Care and Monitoring of Animals}

Intestinal adaptation, as the pivotal process occurring after extended intestinal resection, proved to be influenced by the amount $[5,20,35,48]$ and quality of enterally applied nutrients [5]. To allow for comparison between animals in similar conditions, Benhamou et al. [35] chose the pair feeding method. Some other authors monitored food intake for at least a week $[18,25,27]$ to control nutrient uptake. Besides the quantity of food, the type of food also seems to be important. To simulate the conditions in infants and children, polymeric infant formula and elemental formula designed for infants were used [17, 20]. Polymeric diet was associated with a better adaptational response [17, 24]. A diet supplemented with bovine colostrum protein concentrate also showed influences on intestinal adaptation such as 
trophic effects on bowel mucosa [24] and hypertrophy of the smooth muscle of the intestine [16]. Polymeric infant formula together with colostrum protein was found to produce the optimal effects on intestinal adaptation [16, 24]. Also, nonnutritive components of different feedings which result in better uptake of nutrients may promote the physiologic adaptation process in neonates [22].

Body weight is one of the most frequently measured parameters in SBS. Most often, it is measured daily or at least weekly. Generally, failure to gain weight $[10,17-21,23,24,26,27$, 32-35] would be adequate for an SBS model, although some authors only accepted weight loss $[7,25,31,36]$. An increase in body weight was also described as the most important endstage clinical parameter of a successful bowel adaptation in animals [22] with SBS. However, some studies did not even compare weight differences between case and control groups and associated SBS with severe transient diarrhea after massive bowel resection [29]. Besides diarrhea $[21,24,25,29,31]$, a lower efficacy of the feed-to-weight ratio [18] and a lower absorptive function $[7,19,34]$ measurable in decreased nutritional parameters [36] were other common indicators for SBS after extended bowel resection.

\section{Assessment of SBS}

It is important to distinguish two different objectives in publications: the analysis of SBS itself or the effects of interventions on SBS and the use of an SBS model to evaluate other surgical interventions. Assessment criteria of the former are based on the processes which take place after inducing an SBS. Following the loss of extended parts of the small bowel, an upregulation of the ability of the intestine to absorb nutrients occurs [28] resulting in a process called 'intestinal adaptation'. This process is characterized by functional and morphological changes as well as changes in the protein and molecular level $[5,13,17,21,22]$.

To analyze functional changes, body weight, as mentioned before, plays a pivotal role [28]. Additionally, nutrient uptake after extensive intestinal resection was demonstrated to be diminished in fat $[19,27,28]$, protein [28], carbohydrate $[18,27,28]$ and total energy absorption and was therefore measured [18, 27, 28, 49].

Morphological changes occurring in the process of intestinal adaptation [27] have frequently been analyzed. These include macroscopic alterations such as increased length, dilatation and thickening of the intestinal lumen [5,34]. Most studies focused on histological changes and showed that mucosal hyperplasia (associated with an increase in villus height), diameter and depth of the crypts [5, 21, 24, 34, 35] were parameters for intestinal adaptation [21].

In addition to morphological evaluations, molecular analyses are also important. The histological alterations described previously correlate with an increase in weight and protein as well as RNA and DNA content of the mucosa [5, 33]. SBS animals showed alterations in protein levels compared to the other animals [33]. An analysis of concentrations of growth hormone and IGF-1 [16] as well as plasma levels of vasoactive intestinal peptide [40] and proglucagon gene expression [17] were also reported.

\section{Complications of the Different Models}

The SBS model has to harbor a low rate of complications. In the literature, complication rates differ widely depending on the surgical procedures performed. In models where only extended small bowel resection was performed, complication rates ranged from 0 [7, 20, 35] to $18 \%$ [34]. In models combining the SBS model with procedures such as SBTx (44\%) [25] or bowel lengthening $(30-69 \%)[18,19]$, the complication rate often increased $[18,19,25$, $28,36]$. In contrast, other authors reported no complications in combination models [29, 31]. In some studies, it was not declared whether or not complications occurred following surgery $[10,23,26,30,32,33,37]$. Those studies reporting fatal complications are summarized in table 6 . 
Table 6. Fatal complications using a porcine SBS model

\begin{tabular}{|c|c|c|c|c|}
\hline First author & With/without intervention & Total, $\mathrm{n}$ & Death, $n$ & Fatal complication \\
\hline Llanos [36], 2006 & with/without SBTx & 21 & 6 & sepsis $(n=6)$ \\
\hline Pakarinen [25], 1996 & with/without SBTx & 27 & 8 & $\begin{array}{l}\text { anastomotic leak }(n=1) \text {, internal hernia }(\mathrm{n}=3) \text {, stoma prolapse } \\
(\mathrm{n}=1) \text {, ileus }(\mathrm{n}=2) \text {, arterial mesenteric thrombosis }(\mathrm{n}=1)\end{array}$ \\
\hline Buie [18], 1993 & $\begin{array}{l}\text { with/without Bianchi procedure } 6 \text { weeks } \\
\text { after resection }\end{array}$ & 24 & 7 & $\begin{array}{l}\text { intussusception }(n=1 \text { sham }) \text {, acute gastric dilation }(n=1 S B) \text {, } \\
\text { obstruction }(n=1 S B, n=2 S B+\text { Bianchi), sudden death } \\
(n=1 S B+\text { Bianchi), anastomotic leak }(n=1 S B+\text { Bianchi })\end{array}$ \\
\hline Chang [19], 2006 & $\begin{array}{l}\text { with/without dilatation Op, bowel } \\
\text { resection, STEP }\end{array}$ & 10 & 3 & $\begin{array}{l}\text { technical error }(n=1) \text {, massive upper gastrointestinal } \\
\text { hemorrhage }(n=2)\end{array}$ \\
\hline Sigalet [28], 2001 & $\begin{array}{l}\text { with/without cimetidine and codeine } \\
\text { with/without isoperistaltic interposition } \\
\text { of distal colon } \\
\text { with/without bowel lengthening }\end{array}$ & 24 & 3 & bowel obstruction $(\mathrm{n}=3)$ \\
\hline Heemskerk [21], 1999 & no & 16 & 1 & $?$ \\
\hline Heemskerk [22], 2002 & no & 24 & 3 & $?$ \\
\hline Nagy [24], 2004 & no & 37 & 2 & bowel perforation $(n=1)$, mesenteric torsion $(n=1)$ \\
\hline Sigalet [27], 1990 & no & 14 & 2 & anastomotic stricture $(\mathrm{n}=1)$, bowel obstruction $(\mathrm{n}=1)$ \\
\hline Turner [34], 2011 & no & 28 & 5 & anastomotic leak $(n=1)$, sepsis $(n=4)$ \\
\hline
\end{tabular}

\section{Conclusion}

In order to choose an appropriate SBS model, it is important to consider that the descriptions of those models currently in use are very heterogeneous, sometimes imprecise and highly dependent on the aim of the planned study. A uniform definition of SBS is missing along with a consistent method of induction in an animal model. As enteral alimentation is not sufficient to provide an adequate nutrient supply in SBS, the most important point for the induction of SBS in an animal model would be the reduction of weight gain in growing pigs or weight loss in pigs with stable weight. The majority of authors tried to establish this model through a $75 \%$ midintestinal resection with the preservation of the ileocecal valve. This may define a common practical model of SBS in pigs. However, it remains pivotal to tailor the model according to the aim of the study.

\section{Acknowledgements}

This work has been supported by a grant from the 'Heidelberger Stiftung Chirurgie'. Besides that, there was no sponsorship or funding arrangements.

\section{Disclosure Statement}

None of the authors have any conflicts of interest.

\section{References}

1 Weih S, Kessler M, Fonouni H, Golriz M, Hafezi M, Mehrabi A, Holland-Cunz S: Current practice and future perspectives in the treatment of short bowel syndrome in children - a systematic review. Langenbecks Arch Surg 2012;397:1043-1051.

2 Goulet O, Sauvat F: Short bowel syndrome and intestinal transplantation in children. Curr Opin Clin Nutr Metab Care 2006;9:304-313.

3 Sala FG, Kunisaki SM, Ochoa ER, Vacanti J, Grikscheit TC: Tissue-engineered small intestine and stomach form from autologous tissue in a preclinical large animal model. J Surg Res 2009;156:205-212. 
- 4 Koffeman GI, van Gemert WG, George EK, Veenendaal RA: Classification, epidemiology and aetiology. Best Pract Res Clin Gastroenterol 2003;17:879-893.

5 Digalakis M, Papamichail M, Glava C, Grammatoglou X, Sergentanis TN, Papalois A, Bramis J: Interposition of a reversed jejunal segment enhances intestinal adaptation in short bowel syndrome: an experimental study on pigs. J Surg Res 2011;171:551-557.

- 6 Fishbein TM: Intestinal transplantation. N Engl J Med 2009;361:998-1008.

- 7 Sacher P, Stauffer UG: An animal model for short-bowel syndrome in piglets to assess the efficiency of bowellengthening procedures. Eur J Pediatr Surg 1997;7:207-211.

- 8 Jayarajan S, Daller JA: Reverse intestinal interposition: a model for living related small bowel transplantation? J Surg Res 2011;169:192-193.

- 9 Xu HM, Wang ZJ, Han JG, Ma HC, Zhao B, Zhao BC: Application of acellular dermal matrix for intestinal elongation in animal models. World J Gastroenterol 2010;16:2023-2027.

10 Welters CF, Deutz NE, Dejong CH, Soeters PB, Heineman E: Supplementation of enteral nutrition with butyrate leads to increased portal efflux of amino acids in growing pigs with short bowel syndrome. J Pediatr Surg 1996; 31:526-529.

11 Nishida S, Komokata T, Ogata S, Ikoma A, Hamada N, Matsumoto H, Ushijima T, Tanaka K, Yoshida H, Taira A: Allograft rejection of small bowel transplantation in pigs. Surg Today 1998;28:1138-1145.

12 Oliverius M, Balaz P, Kudla M, Valsamis A, Cap J, Adamec M: Small bowel graft revascularization in experiment. Bratisl Lek Listy 2009;110:65-68.

-13 Pereira-Fantini PM, Thomas SL, Wilson G, Taylor RG, Sourial M, Bines JE: Short- and long-term effects of small bowel resection: a unique histological study in a piglet model of short bowel syndrome. Histochem Cell Biol 2011;135:195-202.

14 Weih S, Kessler M, Fonouni H, Golriz M, Nickkholgh A, Schmidt J, Holland-Cunz S, Mehrabi A: Review of various techniques of small bowel transplantation in pigs. J Surg Res 2011;171:709-718.

15 Moher D, Cook DJ, Eastwood S, Olkin I, Rennie D, Stroup DF: Improving the quality of reports of meta-analyses of randomised controlled trials: the QUOROM statement. QUOROM group. Br J Surg 2000;87:1448-1454.

-16 Pereira-Fantini PM, Thomas SL, Taylor RG, Nagy E, Sourial M, Fuller PJ, Bines JE: Colostrum supplementation restores insulin-like growth factor-1 levels and alters muscle morphology following massive small bowel resection. JPEN J Parenter Enteral Nutr 2008;32:266-275.

17 Bines JE, Taylor RG, Justice F, Paris MC, Sourial M, Nagy E, Emselle S, Catto-Smith AG, Fuller PJ: Influence of diet complexity on intestinal adaptation following massive small bowel resection in a preclinical model. J Gastroenterol Hepatol 2002;17:1170-1179.

18 Buie WD, Thurston OG, vanAerde JE, Aherne FX, Thomson AB, Fedorak RN: Jejunum is preferable for construction of a Bianchi bowel-lengthening procedure in swine short bowel. J Pediatr Surg 1993;28:102109.

19 Chang RW, Javid PJ, Oh JT, Andreoli S, Kim HB, Fauza D, Jaksic T: Serial transverse enteroplasty enhances intestinal function in a model of short bowel syndrome. Ann Surg 2006;243:223-228.

20 Healey KL, Bines JE, Thomas SL, Wilson G, Taylor RG, Sourial M, Pereira-Fantini PM: Morphological and functional changes in the colon after massive small bowel resection. J Pediatr Surg 2010;45:1581-1590.

-21 Heemskerk VH, van Heurn LW, Farla P, Buurman WA, Piersma F, ter Riet G, Heineman E: A successful shortbowel syndrome model in neonatal piglets. J Pediatr Gastroenterol Nutr 1999;29:457-461.

22 Heemskerk VH, van Heurn LW, Farla P, Buurman WA, Piersma F, ter Riet G, Heineman E: Effect of IGF-rich colostrum on bowel adaptation in neonatal piglets with short bowel syndrome. J Pediatr Gastroenterol Nutr 2002;34:47-51.

-23 Modi BP, Ching YA, Langer M, Donovan K, Fauza DO, Kim HB, Jaksic T, Nurko S: Preservation of intestinal motility after the serial transverse enteroplasty procedure in a large animal model of short bowel syndrome. J Pediatr Surg 2009;44:229-235; discussion 235.

-24 Nagy ES, Paris MC, Taylor RG, Fuller PJ, Sourial M, Justice F, Bines JE: Colostrum protein concentrate enhances intestinal adaptation after massive small bowel resection in juvenile pigs. J Pediatr Gastroenterol Nutr 2004; 39:487-492.

-25 Pakarinen M, Kuusanmaki P, Halttunen J: Ileal nutritional function after one-stage orthotopic ileum transplantation in the growing pig: reversal of lethal short bowel syndrome. J Pediatr Surg 1996;31:686-694.

-26 Paris MC, Fuller PJ, Carstensen B, Nagy E, Taylor RG, Sourial M, Holst JJ, Hartmann B, Binesm JE: Plasma GLP-2 levels and intestinal markers in the juvenile pig during intestinal adaptation: effects of different diet regimens. Dig Dis Sci 2004;49:1688-1695.

-27 Sigalet DL, Lees GM, Aherne F, Van Aerde JE, Fedorak RN, Keelan M, Thomson AB: The physiology of adaptation to small bowel resection in the pig: an integrated study of morphological and functional changes. J Pediatr Surg 1990;25:650-657.

28 Sigalet DL, Lees GM, Aherne FX, Fedorak R, Keelan M, Thomson AB, van Aerde J: Nutritional effects of surgical and medical treatment for short bowel syndrome. JPEN J Parenter Enteral Nutr 2001;25:330-336.

29 Taguchi S, Masumoto K, Yamanouchi T, Suita S: Decrease in hepatic circulation induces hepatic fibrosis in a neonatal piglet model with short bowel syndrome. J Pediatr Surg 2005;40:1592-1597.

-30 Sano N, Nio M, Ishii T, Amae S, Wada M, Nishi K, Endo N, Hayashi Y, Ohi R: Oral FK 506 blood levels are elevated in pig short bowel model: further investigations with co-administration of an intestinal CYP3A4 inhibitor. Transplant Proc 2002;34:1050-1051. 
-31 Sano N, Nio M, Shimaoka S, Ishii T, Amae S, Wada M, Ohi R: High trough levels of oral FK506 induced by loss of small intestine. Pediatr Transplant 2001;5:434-438.

-32 Pereira-Fantini PM, Nagy ES, Thomas SL, Taylor RG, Sourial M, Paris MC, Holst JJ, Fuller PJ, Bines JE: GLP-2 administration results in increased proliferation but paradoxically an adverse outcome in a juvenile piglet model of short bowel syndrome. J Pediatr Gastroenterol Nutr 2008;46:20-28.

-33 Stephens AN, Pereira-Fantini PM, Wilson G, Taylor RG, Rainczuk A, Meehan KL, Sourial M, Fuller PJ, Stanton PG, Robertson DM, Bines JE: Proteomic analysis of the intestinal adaptation response reveals altered expression of fatty acid binding proteins following massive small bowel resection. J Proteome Res 2010;9:1437-1449.

-34 Turner JM, Wales PW, Nation PN, Wizzard P, Pendlebury C, Sergi C, Ball RO, Pencharz PB: Novel neonatal piglet models of surgical short bowel syndrome with intestinal failure. J Pediatr Gastroenterol Nutr 2011;52:9-16.

-35 Benhamou PH, Canarelli JP, Richard S, Cordonnier C, Postel JP, Grenier E, Leke A, Dupont C: Human recombinant growth hormone increases small bowel lengthening after massive small bowel resection in piglets. J Pediatr Surg 1997;32:1332-1336.

- 36 Llanos JC, Bakonyi Neto A, Lerco MM, Clark RM, Polachini do Valle A, Sousa MM: Induction of short gut syndrome and transplantation in a porcine model. Transplant Proc 2006;38:1855-1856.

-37 Bartholome AL, Albin DM, Baker DH, Holst JJ, Tappenden KA: Supplementation of total parenteral nutrition with butyrate acutely increases structural aspects of intestinal adaptation after an $80 \%$ jejunoileal resection in neonatal piglets. JPEN J Parenter Enteral Nutr 2004;28:210-222; discussion 222-223.

-38 Kieninger G: Duenndarmgegenschaltung zur Malassimilationsbehandlung nach subtotaler Duenndarmresektion. Med Klin 1977;72:554-559.

39 Luntz J, Brei D, Teitelbaum D, Spencer A: Mechanical extension implants for short-bowel syndrome. Proc Soc Photo Opt Instrum Eng 2006;6173:617309.

40 Del Olmo M, Carbajo Caballero MA, Blanco Alvarez JI, Audivert Mena L, Vaquero Puerta C: Decrease in plasma levels of vasoactive intestinal polypeptide in short bowel syndrome: experimental study. Int Surg 1998;83: 150-153.

41 Pakarinen MP, Lauronen J, Pirinen P, Kuusanmaki P, Raivio P, Halttunen J: Octreotide in the treatment of small intestinal dysfunction after a model of jejunoileal autotransplantation in the pig. Pediatr Surg Int 2004;20: 791-796.

42 Miller ER, Ullrey DE: The pig as a model for human nutrition. Annu Rev Nutr 1987;7:361-382.

-43 Moughan PJ, Birtles MJ, Cranwell PD, Smith WC, Pedraza M: The piglet as a model animal for studying aspects of digestion and absorption in milk-fed human infants. World Rev Nutr Diet 1992;67:40-113.

44 Mike A, Varley JW (eds): The Weaner Pig: Nutrition and Management. Wallingford, CAB International, 2001, vol 1.

45 Smith AC, Swindle MM: Preparation of swine for the laboratory. ILAR J 2006; 47:358-363.

46 Swindle MM: Surgery, Anesthesia and Experimental Techniques in Swine. Ames, Iowa State University Press, 1998.

47 Kimura K, LaRosa CA, Blank MA, Jaffe BM: Successful segmental intestinal transplantation in enterectomized pigs. Ann Surg 1990;211:158-164.

48 Dodou D, van den Berg M, van Gennip J, Breedveld P, Wieringa PA: Mucoadhesive films inside the colonic tube: performance in a three-dimensional world. J R Soc Interface 2008;5:1353-1362.

49 Papadia C, Sherwood RA, Kalantzis C, Wallis K, Volta U, Fiorini E, Forbes A: Plasma citrulline concentration: a reliable marker of small bowel absorptive capacity independent of intestinal inflammation. Am J Gastroenterol 2007;102:1474-1482. 